Article

\title{
Impacts of Weather Types on Soil Erosion Rates in Vineyards at "Celler Del Roure" Experimental Research in Eastern Spain
}

\author{
Jesús Rodrigo-Comino ${ }^{1,2, * \mathbb{C}}$, José María Senciales-González ${ }^{3}{ }^{\circledR}$, Enric Terol ${ }^{4}$, \\ Gaspar Mora-Navarro ${ }^{4}$, Yeboah Gyasi-Agyei ${ }^{5}$ and Artemi Cerdà ${ }^{2}$ (D) \\ 1 Department of Physical Geography, University of Trier, 54296 Trier, Germany \\ 2 Soil Erosion and Degradation Research Group. Department of Geography, Valencia University, \\ Blasco Ibàñez, 28, 46010 Valencia, Spain; artemio.cerda@uv.es \\ 3 Department of Geography, University of Málaga, 29079 Málaga, Spain; senciales@uma.es \\ 4 Department of Cartographic Engineering, Geodesy, and Photogrammetry, Universitat Politècnica de \\ València, Camino de Vera, s/n, 46022 Valencia, Spain; eterol@cgf.upv.es (E.T.); joamona@cgf.upv.es (G.M.-N.) \\ 5 School of Engineering and Technology, Central Queensland University, Rockhampton, QLD 4702, Australia; \\ y.gyasi-agyei@cqu.edu.au \\ * Correspondence: rodrigo-comino@uma.es
}

Received: 29 April 2020; Accepted: 22 May 2020; Published: 26 May 2020

\begin{abstract}
To understand soil erosion processes, it is vital to know how the weather types and atmospheric situations, and their distribution throughout the year, affect the soil erosion rates. This will allow for the development of efficient land management practices to mitigate water-induced soil losses. Vineyards are one of the cultivated areas susceptible to high soil erosion rates. However, there is a lack of studies that link weather types and atmospheric conditions to soil erosion responses in viticultural areas. Thus, the main aim of this research is to assess the impacts of weather types and atmospheric conditions on soil erosion processes in a conventional vineyard with tillage in eastern Spain. To achieve this goal, rainfall events from 2006 to 2017 were monitored and the associated runoff and soil loss were collected from experimental plots. Our results showed that the highest volume of runoff and soil erosion is linked to rainfall associated with the eastern winds that accounted for $59.7 \%$ of runoff and $63.9 \%$ of soil loss, while cold drops in the atmospheric situation classifications emerged as the highest contributor of $40.9 \%$ in runoff and $44.1 \%$ in soil loss. This paper provides new insights into the development of soil erosion control measures that help to mitigate the negative impact of extreme rainfall and runoff considering atmospheric conditions.
\end{abstract}

Keywords: soil loss; runoff; weather types; vineyards; cold drops.

\section{Introduction}

Research studies related to soil erosion processes are becoming important and more relevant due to the negative impacts that soil loss exerts on soil quality and fertility in agricultural fields $[1,2]$. Moreover, the rural and urban areas, including transport infrastructures, that receive the sediments and runoff are damaged [3-5]. Thus, soil erosion is more than the loss of sediments as it also poses risks to human societies [6,7]. Understanding which factors play key roles in runoff generation and subsequent soil loss is crucial to the design of proper land management plans [8,9]. Despite the huge amount of studies published in the last decades, the contribution of each of the factors governing the soil erosion process is still not clear [6,10]. The scientific literature highlight two key factors that control soil erosion rates, these being rainfall and soil management $[11,12]$. There is abundant literature on the effects of soil management on soil erosion [13-15], within which there is a long list of sustainable land 
use and land management options $[16,17]$. However, the literature is limited to the impacts of climate on soil erosion, the majority of which are on climate change [18] and rain erosivity [19]. Topics such as rainfall characteristics are relevant factors in the soil erosion process, and so is the origin of the air masses and weather types [20].

The types of rainfall events are determined by raindrop characteristics [21,22], rainfall intensity [23,24], duration and total volume $[25,26]$. These rainfall characteristics determine the activation of runoff and total discharge along the hillslopes and watersheds [27]. Among the factors controlling soil erosion, the climate is relevant and deserves more attention to properly understand and foresee its impacts on soil erosion processes and desertification [28-30]. Studies along climatological gradients have been widely researched and the relationships between climate and soil erosion processes have been demonstrated [31,32]. To shed more light on the impact of climate on soil erosion processes and rates, it will be useful to assess the impacts of weather types (WTs) on soil erosion.

The use of WTs to assess soil erosion is a new approach that will contribute to a better understanding of the soil erosion processes and to predict the impact of climate change on soil erosion. Peña-Angulo et al. [33] confirmed that this characterization allows an understanding of the main situations under which runoff and soil losses occur, giving new useful information for assessing and predicting the spatial variability of soil erosion processes. The relationship between the synoptic WTs, runoff and sediments have been successfully studied in a Mediterranean mountain landscape [20] and several Mediterranean soil erosion plots [34]. Their main results highlighted that most of the rainfall, runoff and soil losses were generated by a relatively small number of daily events, and just a few WTs contributed to nearly all the total amounts. It is well-known that the soil losses are concentrated in a few days due to the control rainfall intensity exerts on soil erosion rates [35,36]. However, it is yet to be ascertained whether this analysis can bring new insights into agricultural research and soil erosion. Rodrigo-Comino et al. [37] performed the first weather-type induced-soil erosion analysis in a Mediterranean vineyard where an abandoned field and an active field were compared. Their results with slightly more than 20 rainfall events did not show any clear trend and soil management seemed to be the overriding factor. It is believed that soil erosion research requires a large number of rainfall events that involve long-term monitoring for the results to be conclusive [38]. Thus, this paper is based on a long series of field trial measurements to shed more light on this issue.

Developing a new soil erosion research approach is relevant to assist in the design of sustainable soil management systems that will contribute to reducing soil erosion rates. It is well known that the use of cover crops, organic amendments and the reduction of heavy machinery used in some hotspots in cultivated areas are the most successful erosion control measures $[39,40]$. These soil management systems are relevant in vineyards, which are one of the agricultural fields that register the highest soil erosion rates worldwide [41]. However, to develop the most sustainable management system, we need to get more information on other factors such as rainfall characteristics and distribution, making research of WTs more relevant as this will help us to understand soil erosion processes. This paper contributes to this understanding.

The main aim of this research is to assess the impacts of WTs on soil erosion processes considering a conventionally tilled vineyard in Eastern Spain using a long-term (2006-2017) dataset obtained from $2 \mathrm{~m}^{2}$ soil erosion plots. We hypothesize that only a few of the WTs are responsible for most of the soil losses, and, therefore, soil erosion control strategies should be implemented considering the seasons in which these WTs occur.

\section{Materials and Methods}

\subsection{Study Area}

We selected a plot from the traditional viticulture region of Terres dels Alforins, in Valencia province (Valencia, eastern Spain). The experimental area is located in the Les Alcusses valley within the Moixent municipality (Figure 1). It is about $60 \mathrm{~km}$ from the Mediterranean Sea, elevation varying 
between 550 and $750 \mathrm{~m}$ a.s.l. The study area is a representative vineyard managed by conventional tillage on a colluvial low lying area (footslope position) with active past and current erosion processes influenced by human and natural factors [42]. The vineyards produce grapes and wine for the Celler del Roure winery using the Monastrell grape variety among others. The 30-year-old vineyards are planted with a framework system of $3.0 \mathrm{~m} \times 1.4 \mathrm{~m}$. All the rows and inter-rows are tilled three times per year by a tractor that tills the soil to a depth of about $25 \mathrm{~cm}$, redistributing the material from the inter-row to the row area in the same upslope direction. The soil surface is devoid of vegetation cover and the soils have low organic matter content (from $1.1 \%$ to $1.5 \%$ ) due to the use of herbicides. Nevertheless, during some periods of the year, some vegetation cover can be found underneath the vines. The general inclination of each inter-row area is lower than $5 \%$. Cretaceous limestones and Tertiary marl deposits containing deep $(>5 \mathrm{~m})$ colluvium are the main parent materials [43], and the soils are classified as terric Anthrosol with colluvic materials [44]. The observed soil profile depths range between 40 and $60 \mathrm{~cm}$ and are homogeneous due to decades of tillage. The soil texture is sandy-loam and the rock fragment cover ranges from $25 \%$ to $40 \%$ but the mean volume in the soil profile is lower than $10 \%$ [45].
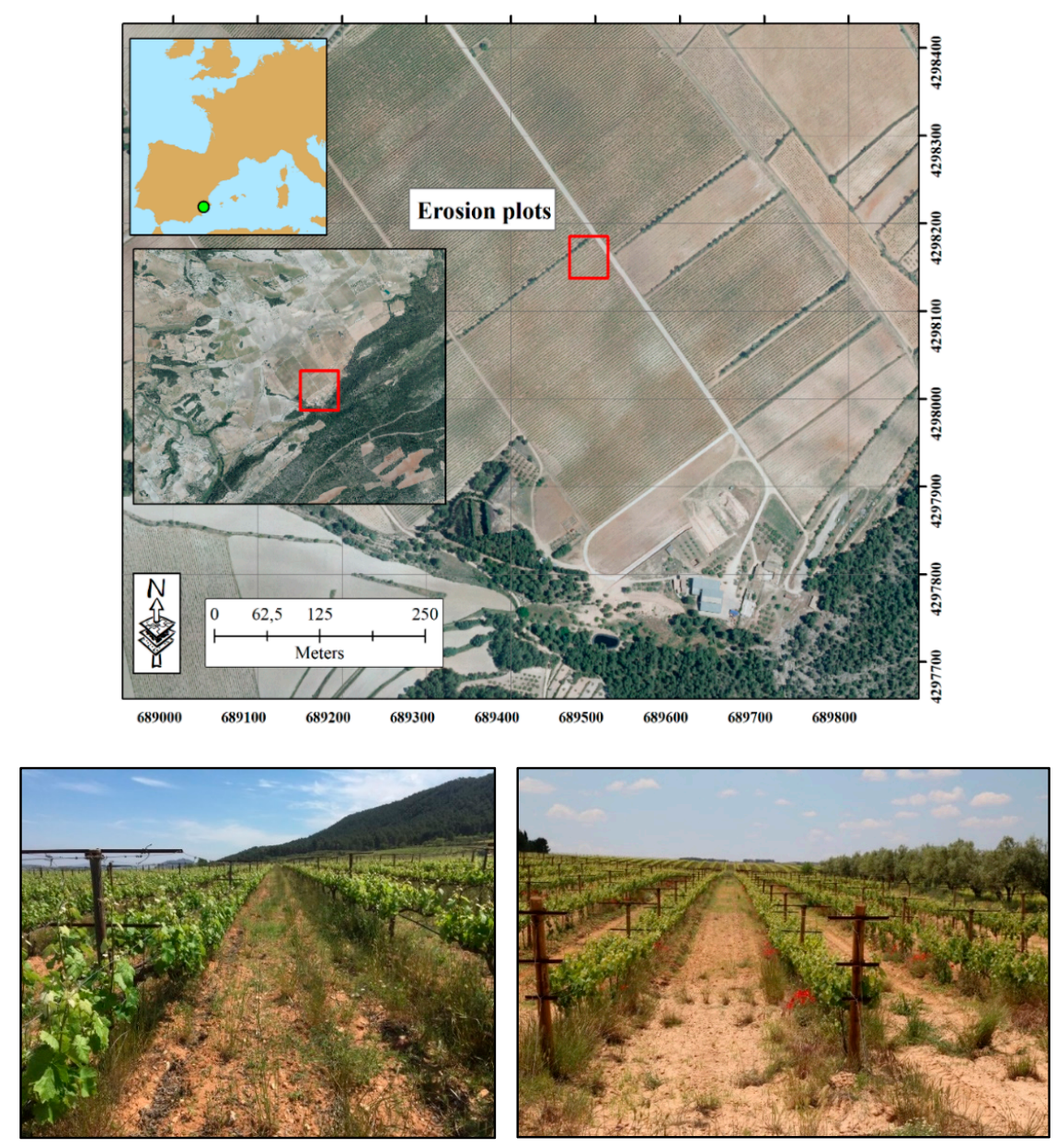

Figure 1. Study area located in the Terres dels Alforins belonging to the Celler del Roure winery. Source: Aerial Photography (IGN, Spain: https://es.ign.com/)

The climate is characterized by typical Mediterranean conditions with an average annual temperature of $15{ }^{\circ} \mathrm{C}$. Normally, drought persists between June and September with a mean total annual rainfall of $400 \mathrm{~mm} \mathrm{yr}^{-1}$. However, maximum peaks of rainfall intensities during autumn (September to November) can reach $100 \mathrm{~mm} \mathrm{day}^{-1}$, and summer (June to August) thunderstorms can 
reach $40 \mathrm{~mm} \mathrm{~h}^{-1}$. Rills, ephemeral gullies, landslides and floods can be noted after extreme rainfall events [46].

\subsection{Rainfall Events, Soil Loss and Runoff Data Collection}

A total of 775 rainfall events were selected from the continuous rainfall records of the meteorological station of Fontanars dels Alforins (AEMET-Agencia Estatal de Meteorología). A rainfall event is separated by a minimum of continuous 6 dry hours and having a minimum total rainfall value of $1 \mathrm{~mm}$. All single-day $(24 \mathrm{~h})$ events were then counted. For multi-day events, only those that retained the same weather type and wind surface direction, or recorded no erosion, were counted.

A total of 4 pairs of sediment collectors installed on $2 \mathrm{~m}^{2}$ ( $1 \mathrm{~m}$ width $\times 2 \mathrm{~m}$ length) soil erosion plots were used to monitor runoff and soil loss in the tilled vineyard. Each plot boundary was demarcated by galvanized iron sheets $(1 \mathrm{~mm}$ thick $\times 50 \mathrm{~mm}$ in height) and a $50 \mathrm{~L}$ container was installed at the outlet to collect the runoff and soil losses. The plots were laid in the inter-row areas close to the vine rows to avoid problems with the tractor passes. The collected sediment-laden runoff samples in the containers were transported to the laboratory after each rainfall event, weighed and air-dried to separate and quantify runoff and soil loss. The average values of runoff $\left(\mathrm{l} \mathrm{m}^{-2}\right)$ and soil loss $\left(\mathrm{g} \mathrm{m}^{-2}\right)$ of the 8 collectors represented the event.

\subsection{Assessment of Weather Types}

The 775 rainfall events were analyzed and grouped according to their duration. The classification of the different WTs registered in the study area was performed using the method applied to the Iberian Peninsula by [47] and [48] using visual analysis of maps and the following objective criteria [49-51]: the barometric pressure at the surface and $500 \mathrm{hPa}$ (https://www.wetterzentrale.de/; http://www.aemet.es/es/portada) level, and the dominant wind at the surface and $500 \mathrm{hPa}$ level. Based on this, the WTs were cataloged and related to volumes and numbers of rainfall and soil erosion events, as well as their statistical significance. The types of atmospheric situations identified using synoptic maps during each event are the following:

(1) Dynamic low-pressure without fronts (DLp). They are usually dynamic low-pressure events but without the presence of associated fronts throughout the event, or, at least, on the day of precipitation, or near the location zone of the weather station. The wind direction usually indicates the position of this mentioned depression.

(2) Thermal low-pressure (TLp). These are spring, summer or autumnal rainfall events (usually the first) characterized by low surface pressure but high at $500 \mathrm{hPa}$ levels. They may or may not be associated with frontal systems.

(3) Dynamic low-pressure with fronts (DLp+f). They are dynamic low-pressure weather systems that occur at high levels in the atmosphere. The wind direction usually indicates the position of that low-pressure, although it is the presence of the frontal system that usually determines the final precipitation. Sometimes the passage of up to three fronts is recorded on the same day.

(4) Cold drop (CD). To identify cold drops and separate them from low-pressure weather systems with cold-air damming in height. The fundamental criterion considered in this study was the absence of low surface pressure. Therefore, any positive pressure element $(>1014 \mathrm{hPa}$ on the surface) that is accompanied by a cold air cell developed in height has been considered as a cold drop.

(5) High-pressure weather systems with fronts $(\mathrm{HP}+\mathrm{f})$. Sometimes, high pressures do not prevent the unstable behavior of air masses, especially when they have an unstable maritime origin due to contact with other masses of a different nature (temperature/humidity). In these cases, it is usual that high-pressure systems show levogyrous curvatures that coincide with the fronts.

(6) Anticyclones/weak pressure weather systems (A). Frequently, barometric swamps determine the appearance of relatively small thermal lows that are difficult to identify or the arrival of 
maritime air laden with moisture. In both cases, the pressure field is undefined, without a marked instability, a priori, but it can result in downpours. In this situation, several downpours of moderate-intensity have been identified.

According to these typologies of cold-air at height, we considered atmospheric situations related to height analysis and specific to low-pressure (LP) events with cold flows to identify cold-air damming (CAD), the cold drops (CD) and high-pressure (HP) events with cold fluxes. Other atmospheric situations that exhibited height inversion were excluded from this analysis as these relate to coastal areas or arid and semi-arid territories. It was assumed for this case study that height analysis was not adequate for soil erosion assessment. The main reason is that some anticyclones with fronts, and some low-pressure systems with fronts, lack cold air at height. This can be noted in the total volume of rainfall where the situations conditioned by the height did not represent even half of the total precipitated volume and less than a third of the total number of rainfall events. It should be clarified, therefore, that the analysis focused on how, and to what extent, the situation at $500 \mathrm{hPa}$ affects the volume and the number of events that have an impact on soil erosion.

Finally, all events were reclassified according to their duration since this is how erosion and runoff values are associated with rainfall events.

\section{Results and Discussion}

\subsection{Rainfall Distribution upon Atmospheric Situations and Weather Types}

Tables 1 and 2 summarize the total rainfall amounts and the number of events recorded during the monitoring period within the different atmospheric situations. The maximum rainfall volume is produced with low dynamic pressure systems with associated fronts $(2247.8 \mathrm{~mm}$ or $45.4 \%)$. Also, it is remarkable to highlight that almost $20 \%$ of that volume was produced by storms ranging from 10 to $30 \mathrm{~mm}$. It was observed that the maximum number of events also occurred with the dynamic low-pressure systems with the associated fronts (325 events or $41.9 \%$ ), with the most frequent rainfall events ranging from 1 to $4.9 \mathrm{~mm}$. The maximum rainfall intensity per day was registered during the cold drops, being the only type of atmospheric situation that usually exceeds $100 \mathrm{~mm} /$ day. On the contrary, milder rains are seen to occur when weak anticyclones or high-pressure systems are recorded.

Table 1. Total rainfall based on the atmospheric situation.

\begin{tabular}{cccccccccc}
\hline Atmospheric Situation & Total $\mathbf{( m m})$ & $\mathbf{m m} /$ Day & $\mathbf{> 1 0 0}$ & $\mathbf{5 0 - 9 9 . 9}$ & $\mathbf{3 0 - 5 0}$ & $\mathbf{1 0 - 3 0}$ & $\mathbf{5 - 1 0}$ & $\mathbf{1 - 5}$ & $<\mathbf{1}$ \\
\hline DLp $^{1}$ & 304.7 & 4.5 & 0 & 0 & 36 & 124.2 & 58.9 & 79.3 & 6.3 \\
CD (>1014 hPa) & 1024.8 & 11.4 & 114 & 190.2 & 249.5 & 290.5 & 109.3 & 64.7 & 6.6 \\
TLp with/without fronts & 291.4 & 6 & 0 & 0 & 74.1 & 155 & 15.4 & 40.6 & 6.3 \\
A $^{1}$ & 195.2 & 2.2 & 0 & 0 & 0 & 37.5 & 76 & 68.1 & 13.6 \\
DLp+f & 2247.8 & 6.9 & 0 & 326.5 & 233.9 & 961.1 & 394.2 & 306.8 & 25.3 \\
HP+f & 884.5 & 5.7 & 0 & 59.5 & 104.2 & 409.4 & 160.6 & 131.5 & 19.3 \\
Total & 4948.4 & 6.4 & 114 & 576.2 & 697.7 & 1977.7 & 814.4 & 691 & 77.4 \\
\hline
\end{tabular}

${ }^{1}$ No associated fronts, no flow or cold cells in height.

Table 2. Number of events based on the atmospheric situation.

\begin{tabular}{ccccccccc}
\hline Atmospheric Situation & Total $(\mathbf{m m})$ & $\mathbf{> 1 0 0}$ & $\mathbf{5 0 - 9 9}$ & $\mathbf{3 0 - 4 9 . 9}$ & $\mathbf{1 0 - 2 9 . 9}$ & $\mathbf{5 - 9 . 9}$ & $\mathbf{1 - 4 . 9}$ & $<\mathbf{1}$ \\
\hline DLp $^{1}$ & 68 & 0 & 0 & 1 & 8 & 9 & 33 & 17 \\
CD (>1014 hPa) & 90 & 1 & 3 & 5 & 15 & 15 & 31 & 19 \\
TLp with/without fronts & 49 & 0 & 0 & 2 & 10 & 2 & 20 & 15 \\
A $^{1}$ & 89 & 0 & 0 & 1 & 3 & 11 & 32 & 43 \\
DLp $+f_{\text {HP+f }}$ & 325 & 0 & 5 & 6 & 57 & 58 & 131 & 68 \\
Total & 154 & 0 & 1 & 3 & 25 & 24 & 56 & 45 \\
& 775 & 1 & 9 & 18 & 118 & 119 & 303 & 207 \\
\hline
\end{tabular}


Table 3 presents the number of events, the total and average values of rainfall events as per the WTs. Our results indicated that an elevated proportion of the total rainfall, up to $52 \%$, was originated by eastern WTs totaling $2569.4 \mathrm{~mm}$ (NE; E; S). Also, these WTs constitute up to $35 \%$ of the total rainfall events (275 events). In contrast, the WTs associated with the North, West and South showed a lower number of events at around 120 each. However, the total rainfall of the WTs associated with the South resulted in a much higher rainfall amount $(768 \mathrm{~mm})$, double that for the North or West.

Table 3. Distribution of the number of events $(\mathrm{n})$, total rainfall $(\mathrm{T})$, average total rainfall $(\bar{x})$ and standard deviation $(\sigma)$ of the events displayed for the different weather types.

\begin{tabular}{ccccc}
\hline Weather Type & $\mathbf{n}$ & $\mathbf{T}(\mathbf{m m})$ & $\bar{x}(\mathbf{m m})$ & $\boldsymbol{\sigma}(\mathbf{m m})$ \\
\hline N & 123 & 378 & 3.07 & - \\
E & 275 & 2569.4 & 9.34 & - \\
S & 122 & 768 & 6.30 & - \\
W & 124 & 378 & 3.05 & - \\
Variable (mixed types) & 131 & 855 & 6.53 & - \\
\hline N & 40 & 143.7 & 3.59 & 5.63 \\
N-NE & 6 & 6.2 & 1.03 & 1.35 \\
NE & 87 & 896.9 & 10.31 & 16.11 \\
E-NE & 8 & 149.6 & 18.7 & 19.50 \\
E & 166 & 1465.2 & 8.83 & 14.13 \\
E-SE & 14 & 57.7 & 4.12 & 4.49 \\
SE & 62 & 458.3 & 7.39 & 9.30 \\
S-SE & 3 & 9.7 & 3.23 & 4.20 \\
S & 55 & 298.5 & 5.43 & 8.87 \\
S-SW & 2 & 1.5 & 0.75 & 0.64 \\
SW & 44 & 128.6 & 2.92 & 3.50 \\
W-SW & 8 & 41.3 & 5.16 & 5.26 \\
W & 60 & 178.6 & 2.98 & 3.30 \\
W-NW & 12 & 29.5 & 2.46 & 4.08 \\
NW & 75 & 226.2 & 3.02 & 3.80 \\
N-NW & 2 & 1.9 & 0.95 & 1.20 \\
Mixed & 131 & 855 & 6.53 & 10.38 \\
Total & 775 & 4948.4 & - & - \\
\hline & & & &
\end{tabular}

Figure 2 depicts the typologies of cold-air in height without considering other atmospheric situations that exhibit height inversion as these relate to coastal areas or arid and semi-arid territories [52,53].

Regarding the surface-to-height ratio, the lifting wind associated with cold pools ( $>520 \mathrm{~m}$ in height for $500 \mathrm{hPa}$, but with clear pockets) appears to result in greater volumes and numbers of precipitation events $[54,55]$. However, concerning the proportion of rainfall per day, it is the independent dynamic low-pressure ( $\mathrm{LP}+\mathrm{CAD}$ ) atmospheric situations that are responsible for higher rainfall intensity. Again, $\mathrm{LP}+\mathrm{CAD}$ is associated with the surface lifting wind that can occur during the wet season of some Mediterranean regions [33,56], or as indicated by modeling (with some differences) in southern Africa or mountainous areas $[57,58]$. Regarding the weather type related to the direction of the wind, again the highest volumes correspond to the cold drops with a rising wind. However, the set of low-pressure systems with associated fronts, regardless of the wind direction, are the ones that generate almost half of the rainfall. In this regard, we note that other authors also consider possibly using the term "upper-level lows" in coastal areas [59-61] or Hungary [62]. As for the scenario that most frequently produces rains, there are coincidences with fronts associated with the western winds. Again, it is the low-pressure systems with associated fronts that are responsible for the highest number of precipitation events. Finally, when analyzing the ratio of rainfall per day, the highest number of precipitation events 
are seen to occur during associated fronts, but this time generated by eastern winds. These systems can generate the highest rainfall intensities followed closely by the cold drops with eastern winds [63].

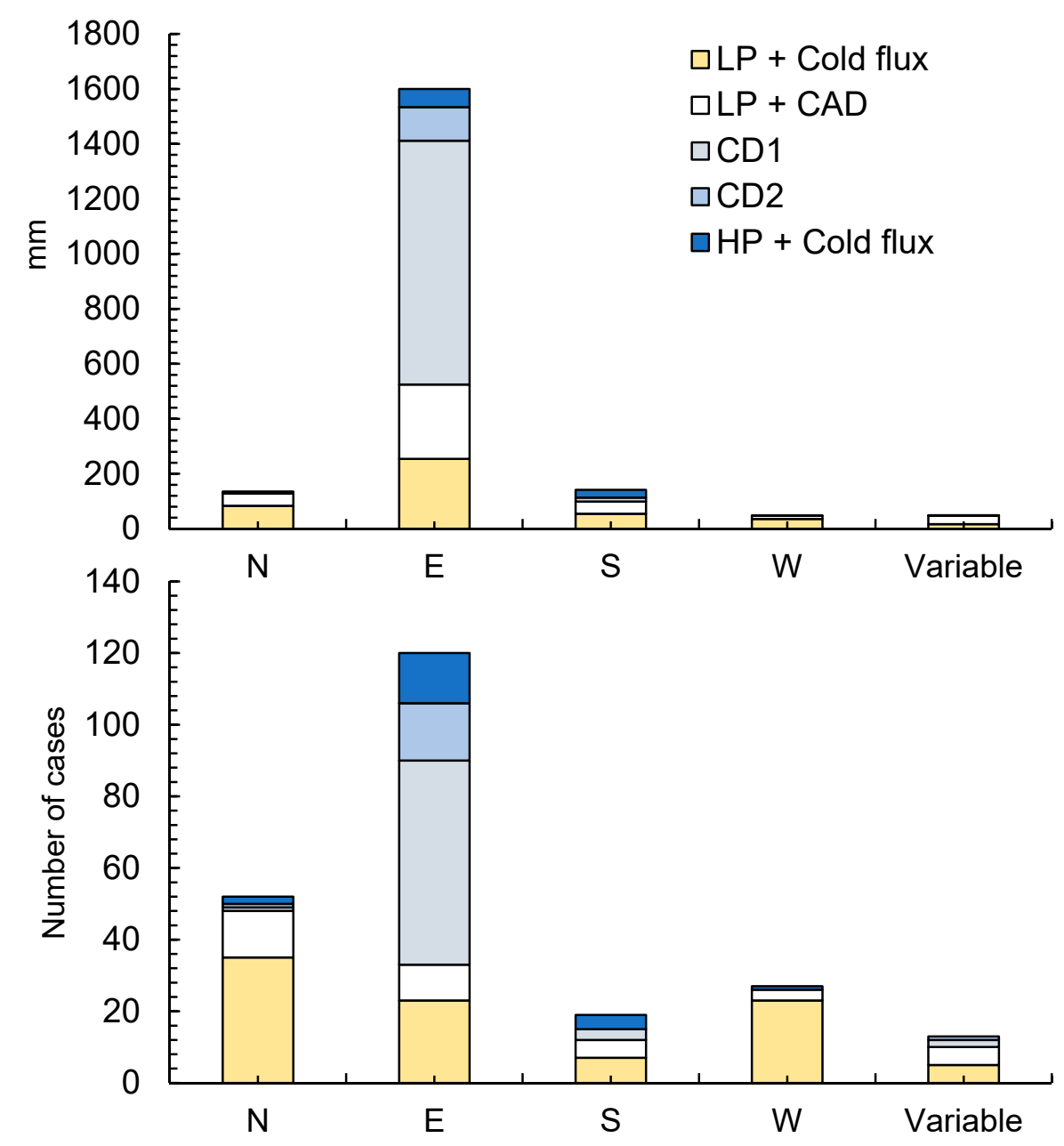

Figure 2. Typologies of cold-air in height summarized as total rainfall from events (top) and the number of events displayed for the different weather types (bottom). LP: low-pressure system; CAD: cold-air damming; CD: cold drop; variable: mixed atmospheric situations.

\subsection{Soil Erosion Events and Weather Types}

A total unit runoff of $238.1 \mathrm{~L} \mathrm{~m}^{-2}$ and soil loss of $987.9 \mathrm{~g} \mathrm{~m}^{-2}$ (sediment concentration of $4.14 \mathrm{~g} \mathrm{~L}^{-1}$ ) were generated from 434 grouped rainfall events of the 775 wet days (Table 4). A total of 59 wet days did not generate enough runoff and soil loss to be sampled. So, they were not considered as independent rainfall events but were included in the valid events. 
Table 4. Duration of the selected rainfall events.

\begin{tabular}{ccccc}
\hline Duration (Days) & $\mathbf{n}$ & Valid Events & Not Valid Events & Total (Days) \\
\hline 1 & 265 & 263 & 2 & 265 \\
2 & 91 & 78 & 13 & 182 \\
3 & 32 & 19 & 13 & 96 \\
4 & 21 & 11 & 10 & 84 \\
5 & 6 & 1 & 13 & 70 \\
6 & 5 & 3 & 2 & 30 \\
7 & 2 & 0 & 2 & 24 \\
8 & 3 & 0 & 3 & 0 \\
9 & 0 & 0 & 0 & 10 \\
10 & 1 & 0 & 1 & - \\
\hline Total (events) & 434 & 375 & 59 & 775 \\
\hline Total (days) & 775 & 543 & 232 & 0 \\
\hline
\end{tabular}

n: number of wet days; valid events: rainfall events grouping wet days; not valid events: they do not generate enough runoff and were grouped into other rainfall events.

The number of events for the analysis of the hydric behavior of the soil related to the weather types exceeded $86 \%$ of the total ( 375 of 434 ), although they only accounted for $70 \%$ of the recorded rainy days (543 of 775). With these data, the number of valid events in each weather type was analyzed with the total corresponding runoff and soil loss (Figure 3). With respect to the WTs, east contributed $59.7 \%$ of runoff and $63.9 \%$ of soil loss while, with the atmospheric condition groupings, cold drops contributed the maximum of $40.9 \%$ of runoff and $44.1 \%$ of soil loss. This is followed by north $(24.3 \%$ of total runoff and $21.4 \%$ of total soil loss) and dynamic low-pressure with fronts associated with variable wind throughout the day ( $35.9 \%$ of total runoff and $33.5 \%$ of total soil loss). On the other hand, the less erosive events occurred after the west and north WTs under dynamic low-pressure systems without fronts and anticyclones $(<1 \%)$. Our results corroborate the findings by Nadal-Romero et al., [34] highlighting that just a few westerly, southwesterly and cyclonic WTs provide the highest amounts of rainfall. They highlighted the important role of these in runoff generation, erosion and sediment yield as they coincide with the wettest WTs. However, it is worth highlighting that these authors also confirmed the elevated spatial variable differentiating areas. Some authors even indicated that the results can be quite different depending on the input data, methods and classification used to generate the models [64]. For example, these results are contrary to those presented by Fernández-Raga et al. for Central Spain [65], who estimated that four WTs with a western component generated the highest rainfall amounts and kinetic energy (higher erosive power) than the other ones. This is due to the different location of the sites as, in the western Iberian Peninsula, the main rainfall events are originated in the Atlantic Ocean, while, in the eastern Iberian Peninsula, the east wind coming from the Mediterranean is the main source of water vapor that contributes to the rainfall events with higher volumes and intensities. The location of the study site is a key factor, and this is highlighted in our research as the distance to the sea and height, the main source of water, is paramount for understanding soil erosion distribution throughout the year [66]. Rodrigo-Comino et al. [37] also demonstrated that in addition to WTs and the atmospheric condition, different land management practices (namely abandonment or tillage) can show different soil erosion results. They estimated a bimodality pattern of the WTs in southern Spain (Montes de Málaga), where the highest soil erosion was generated from the western and southeastern types and the lowest ones from the south type $(5.9 \%)$ and at the $500 \mathrm{hPa}$ level. This is an interesting contribution that highlights the need to include WTs, or the atmospheric situation, in the modeling of soil erosion together with land use and management. 


\section{Weather types (\%)}

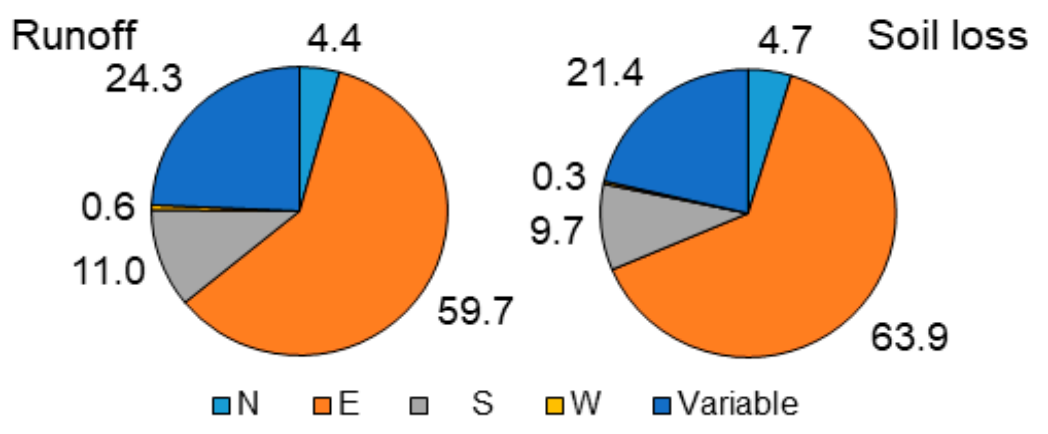

Atmospheric situations (\%)

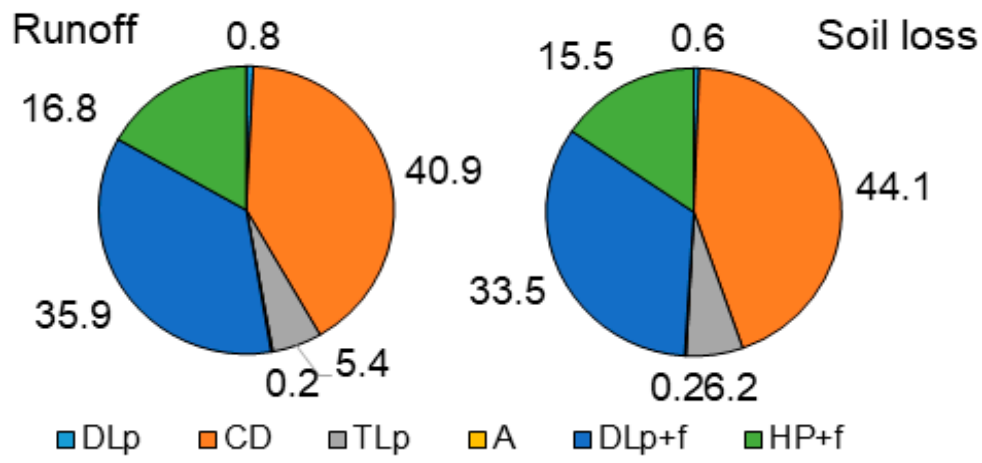

Figure 3. Total runoff and soil loss (\%) based on weather types and atmospheric situations.

\subsection{Challenges and Implications for Future Studies Related to Weather Types and Soil Erosion}

Weather types are not commonly used to assess soil erosion. As we observed, the evaluation of long-term datasets allows the understanding of which atmospheric situations and WTs have more erosive potential to damage cultivated areas [34], with the associated risk of degradation of soil resources for agricultural production. From an agro-meteorological point of view and its classical application, this information could be helpful to the design of effective strategies to mitigate the impacts of some agronomical practices in vineyards such as tillage, the transfer of pollutants during cold drops, and the application of irrigation when expecting rainfall events. Despite the emerging and promising topic of land-use changes and intensive agricultural production and technologies to assess soil erosion, little is known about this poorly studied topic [67]. In this study, we have demonstrated how synoptic WTs in combination with the assessment of the atmospheric situations could be applied to confirm when the most erosive events [68] could occur and when the appropriate soil management practices could be applied or postponed $[69,70]$.

There is limited literature related to WTs and soil erosion. One of the difficulties is related to the standardization of the classification of WTs or the comparison among them to see which is the most effective method [71,72]. Classifications using maps or objective criteria such as geostatistics could be combined with in situ soil erosion estimates as in our current research. However, it is difficult to develop such a long-term database or register a large number of rainfall events in arid and semi-arid areas [73]. In this study, we adapted the use of the WTs classification to analyze some specific regional rainfall events such as cold drops. Given the previous research at the hillslope [37], catchment [20] and regional [33] scales, we considered it vital to compare different territories, cultivated areas, or highlight research gaps that need to be developed.

The contribution of this research is relevant to crop and soil management because it is easy to prevent high erosion rates now that farmers can have access to atmospheric conditions that cause higher erosion rates. One example can be seen in Figure 4. In the eastern Iberian Peninsula, the damage 
comes from the eastern winds and we propose to leave as much plant cover in the field during autumn, which is the period with the strongest east wind and high rainfall volumes and intensities. The plant cover would reduce soil losses such as those that were found in rainfall simulation experiments [74], soil erosion plots [75] and watersheds and basins [76]. Other options to minimize damage during high-intensity rainfall events is to use traditional strategies such as soil bunds [77].
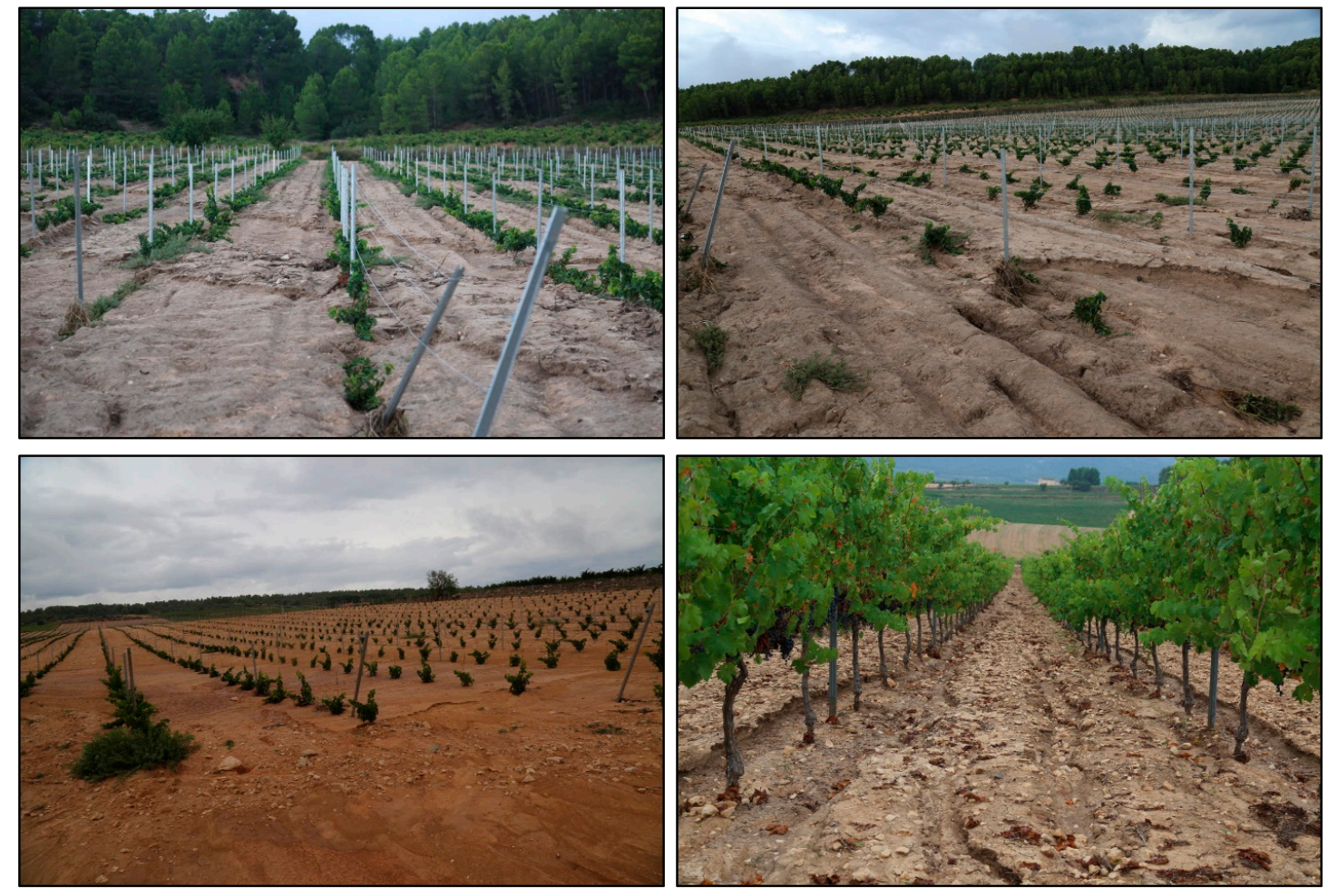

Figure 4. Damage caused during the recurrent loss of soil in the vineyards of eastern Spain.

\section{Conclusions}

Although cold drops are not the most frequent rainfall events in our study area, they were by far the most erosive, and the presence of lifting eastern winds is key to understanding soil erosion activation in the eastern Iberian Peninsula vineyards. On the other hand, weak anticyclones, with a similar number of events, hardly showed any erosive response. Thermal and dynamic low-pressure weather systems show a similar soil erosion response, although, in the case of thermal systems, the variable wind direction seems to register the most erosive response. Regarding the dynamic low-pressure systems, they also reach the maximum runoff and soil loss values, but there is a strong influence from certain wind directions (E and S). Finally, the anticyclones with associated fronts, although they do not reach the values of the cold drops, show the same directions with greater erosive effects, also centered on the eastern and southern winds. This paper gives new insights on the development of erosion control measures with enough lead-time to reduce negative impacts such as cleaning water drainage networks or roads, or to plan soil conservation strategies for autumn, using a statistical correlation between weather type and extreme rainfall events.

Author Contributions: Conceptualization, J.M.S.-G., J.R.-C. and A.C.; methodology, J.M.S.-G., J.R.-C. and A.C.; formal analysis, J.M.S.-G., J.R.-C. and A.C.; investigation, resources and data curation, J.M.S.-G., J.R.-C., E.T., G.M., Y.G.-A. and A.C.; writing-original draft preparation, J.R.-C., J.M.S.-G., E.T., G.M.-N., Y.G.-A. and A.C.; writing-review and editing, J.R.-C., J.M.S.-G., E.T., G.M.-N., Y.G.-A. and A.C. All authors have read and agreed to the published version of the manuscript.

Funding: This research was funded by the European Union Seventh Framework Program (FP7/2007-2013) under grant No. 603498 (RECARE Project). 
Acknowledgments: We acknowledge the Winery Celler del Roure and its owner Pablo Calatayud for providing access to the study area. We thank José Ángel Núnez Mora from AEMET (Agencia Estatal de Meteorología) for the meteorological information and advice. Finally, we would like to thank the guest editor María Fernández-Raga, for inviting us to take part in this special issue of the journal, and two anonymous reviewers for their constructive comments during the review process. The music and lyrics of Luis Eduardo Aute inspired some of the authors in this research.

Conflicts of Interest: The authors declare no conflict of interest.

\section{References}

1. Panagos, P.; Borrelli, P.; Meusburger, K.; van der Zanden, E.H.; Poesen, J.; Alewell, C. Modelling the effect of support practices (P-factor) on the reduction of soil erosion by water at European scale. Environ. Sci. Policy 2015, 51, 23-34. [CrossRef]

2. Stewart, B.A. Soil Erosion: A Threat to Mankind. Ecology 1994, 75, 1193. [CrossRef]

3. Ghafari, H.; Gorji, M.; Arabkhedri, M.; Roshani, G.A.; Heidari, A.; Akhavan, S. Identification and prioritization of critical erosion areas based on onsite and offsite effects. CATENA 2017, 156, 1-9. [CrossRef]

4. Chehlafi, A.; Kchikach, A.; Derradji, A.; Mequedade, N. Highway cutting slopes with high rainfall erosion in Morocco: Evaluation of soil losses and erosion control using concrete arches. Eng. Geol. 2019, 260, 105200. [CrossRef]

5. Streeter, M.T.; Schilling, K.E. Assessing and mitigating the effects of agricultural soil erosion on roadside ditches. J Soils Sediments 2020, 20, 524-534. [CrossRef]

6. García-Ruiz, J.M.; Beguería, S.; Lana-Renault, N.; Nadal-Romero, E.; Cerdà, A. Ongoing and Emerging Questions in Water Erosion Studies. Land Degrad. Dev. 2017, 28, 5-21. [CrossRef]

7. Brevik, E.C.; Steffan, J.J.; Rodrigo-Comino, J.; Neubert, D.; Burgess, L.C.; Cerdà, A. Connecting the public with soil to improve human health. Eur. J. Soil Sci. 2019, 70, 898-910. [CrossRef]

8. Rubio-Delgado, J.; Schnabel, S.; Gómez-Gutiérrez, Á.; Lavado-Contador, J.F. Temporal and spatial variation of soil erosion in wooded rangelands of southwest Spain. Earth Surf. Process. Landf. 2019, 44, 2141-2155. [CrossRef]

9. Benda, L.; James, C.; Miller, D.; Andras, K. Road Erosion and Delivery Index (READI): A Model for Evaluating Unpaved Road Erosion and Stream Sediment Delivery. JAWRA J. Am. Water Resour. Assoc. 2019, 55, 459-484. [CrossRef]

10. García-Ruiz, J.M.; Beguería, S.; Nadal-Romero, E.; González-Hidalgo, J.C.; Lana-Renault, N.; Sanjuán, Y. A meta-analysis of soil erosion rates across the world. Geomorphology 2015, 239, 160-173. [CrossRef]

11. Panagos, P.; Meusburger, K.; Ballabio, C.; Borrelli, P.; Alewell, C. Soil erodibility in Europe: A high-resolution dataset based on LUCAS. Sci. Total Environ. 2014, 479-480, 189-200. [CrossRef]

12. Jie, C.; Jing-zhang, C.; Man-zhi, T.; Zi-tong, G. Soil degradation: A global problem endangering sustainable development. J. Geogr. Sci. 2002, 12, 243-252. [CrossRef]

13. Ricci, G.F.; Jeong, J.; De Girolamo, A.M.; Gentile, F. Effectiveness and feasibility of different management practices to reduce soil erosion in an agricultural watershed. Land Use Policy 2020, 90, 104306. [CrossRef]

14. Novara, A.; Gristina, L.; Guaitoli, F.; Santoro, A.; Cerdà, A. Managing soil nitrate with cover crops and buffer strips in Sicilian vineyards. Solid Earth 2013, 4, 255-262. [CrossRef]

15. Guadie, M.; Molla, E.; Mekonnen, M.; Cerdà, A. Effects of Soil Bund and Stone-Faced Soil Bund on Soil Physicochemical Properties and Crop Yield Under Rain-Fed Conditions of Northwest Ethiopia. Land 2020, 9, 13. [CrossRef]

16. Chevigny, E.; Quiquerez, A.; Petit, C.; Curmi, P. Lithology, landscape structure and management practice changes: Key factors patterning vineyard soil erosion at metre-scale spatial resolution. CATENA 2014, 121, 354-364. [CrossRef]

17. Blavet, D.; De Noni, G.; Le Bissonnais, Y.; Leonard, M.; Maillo, L.; Laurent, J.Y.; Asseline, J.; Leprun, J.C.; Arshad, M.A.; Roose, E. Effect of land use and management on the early stages of soil water erosion in French Mediterranean vineyards. Soil Tillage Res. 2009, 106, 124-136. [CrossRef]

18. Nunes, J.P.; Seixas, J.; Pacheco, N.R. Vulnerability of water resources, vegetation productivity and soil erosion to climate change in Mediterranean watersheds. Hydrol. Process. 2008, 22, 3115-3134. [CrossRef]

19. Nearing, M.A.; Yin, S.; Borrelli, P.; Polyakov, V.O. Rainfall erosivity: An historical review. CATENA 2017, 157, 357-362. [CrossRef] 
20. Nadal-Romero, E.; Cortesi, N.; González-Hidalgo, J.C. Weather types, runoff and sediment yield in a Mediterranean mountain landscape. Earth Surf. Process. Landf. 2014, 39, 427-437. [CrossRef]

21. Fernández-Raga, M.; Palencia, C.; Keesstra, S.; Jordán, A.; Fraile, R.; Angulo-Martínez, M.; Cerdà, A. Splash erosion: A review with unanswered questions. Earth-Sci. Rev. 2017, 171, 463-477. [CrossRef]

22. Marzen, M.; Iserloh, T.; Casper, M.C.; Ries, J.B. Quantification of particle detachment by rain splash and wind-driven rain splash. CATENA 2015, 127, 135-141. [CrossRef]

23. Minea, G.; Ioana-Toroimac, G.; Moro, G. The dominant runoff processes on grassland versus bare soil hillslopes in a temperate environment-An experimental study. J. Hydrol. Hydromech. 2019, 67, 8. [CrossRef]

24. Senciales González, J.M.; Ruiz Sinoga, J.D. Análisis espacio-temporal de las lluvias torrenciales en la ciudad de Málaga. Boletín De La Asoc. De Geógrafos Españoles 2013, 61, 7-24. [CrossRef]

25. Mineo, C.; Ridolfi, E.; Moccia, B.; Russo, F.; Napolitano, F. Assessment of Rainfall Kinetic-Energy-Intensity Relationships. Water 2019, 11, 1994. [CrossRef]

26. Choo, Y.M.; Jo, D.J.; Yun, G.S.; Lee, E.H. A Study on the Improvement of Flood Forecasting Techniques in Urban Areas by Considering Rainfall Intensity and Duration. Water 2019, 11, 1883. [CrossRef]

27. Bryan, R.B. Soil erodibility and processes of water erosion on hillslope. Geomorphology 2000, 32, 385-415. [CrossRef]

28. Angulo-Martínez, M.; Beguería, S. Estimating rainfall erosivity from daily precipitation records: A comparison among methods using data from the Ebro Basin (NE Spain). J. Hydrol. 2009, 379, 111-121. [CrossRef]

29. Ruiz Sinoga, J.D.; Garcia Marin, R.; Martinez Murillo, J.F.; Gabarron Galeote, M.A. Precipitation dynamics in southern Spain: Trends and cycles. Int. J. Climatol. 2011, 31, 2281-2289. [CrossRef]

30. Gholami, H.; Telfer, M.W.; Blake, W.H.; Fathabadi, A. Aeolian sediment fingerprinting using a Bayesian mixing model. Earth Surf. Process. Landf. 2017, 42, 2365-2376. [CrossRef]

31. Cerdà, A. Relationships between climate and soil hydrological and erosional characteristics along climatic gradients in Mediterranean limestone areas. Geomorphology 1998, 25, 123-134. [CrossRef]

32. Lavee, H.; Imeson, A.C.; Sarah, P. The impact of climate change on geomorphology and desertification along a mediterranean-arid transect. Land Degrad. Dev. 1998, 9, 407-422. [CrossRef]

33. Peña-Angulo, D.; Nadal-Romero, E.; González-Hidalgo, J.C.; Albaladejo, J.; Andreu, V.; Bagarello, V.; Barhi, H.; Batalla, R.J.; Bernal, S.; Bienes, R.; et al. Spatial variability of the relationships of runoff and sediment yield with weather types throughout the Mediterranean basin. J. Hydrol. 2019, 571, 390-405. [CrossRef]

34. Nadal-Romero, E.; González-Hidalgo, J.C.; Cortesi, N.; Desir, G.; Gómez, J.A.; Lasanta, T.; Lucía, A.; Marín, C.; Martínez-Murillo, J.F.; Pacheco, E.; et al. Relationship of runoff, erosion and sediment yield to weather types in the Iberian Peninsula. Geomorphology 2015, 228, 372-381. [CrossRef]

35. Gonzalez-Hidalgo, J.C.; Batalla, R.J.; Cerda, A.; de Luis, M. A regional analysis of the effects of largest events on soil erosion. Catena 2012, 95, 85-90. [CrossRef]

36. Martínez-Valderrama, J.; Ibáñez, J.; Del Barrio, G.; Sanjuán, M.E.; Alcalá, F.J.; Martínez-Vicente, S.; Ruiz, A.; Puigdefábregas, J. Present and future of desertification in Spain: Implementation of a surveillance system to prevent land degradation. Sci. Total Environ. 2016, 563-564, 169-178. [CrossRef]

37. Rodrigo-Comino, J.; Senciales, J.M.; Sillero-Medina, J.A.; Gyasi-Agyei, Y.; Ruiz-Sinoga, J.D.; Ries, J.B. Analysis of Weather-Type-Induced Soil Erosion in Cultivated and Poorly Managed Abandoned Sloping Vineyards in the Axarquía Region (Málaga, Spain). Air Soil Water Res. 2019, 12, 1178622119839403. [CrossRef]

38. Cerdà, A.; Rodrigo-Comino, J.; Novara, A.; Brevik, E.C.; Vaezi, A.R.; Pulido, M.; Giménez-Morera, A.; Keesstra, S.D. Long-term impact of rainfed agricultural land abandonment on soil erosion in the Western Mediterranean basin. Prog. Phys. Geogr. Earth Environ. 2018, 42, 202-219. [CrossRef]

39. Novara, A.; Cerdà, A.; Dazzi, C.; Lo Papa, G.; Santoro, A.; Gristina, L. Effectiveness of carbon isotopic signature for estimating soil erosion and deposition rates in Sicilian vineyards. Soil Tillage Res. 2015, 152, 1-7. [CrossRef]

40. Rodrigo-Comino, J.; Lassu, T.; González, J.M.S.; Sinoga, J.D.R.; Seeger, K.M.; Ries, J.B. Estudio de procesos geomorfodinámicos en campos cultivados de viñedos sobre laderas en pendientes en el valle del Ruwer (Alemania). Cuad. Geográficos 2015, 54, 6-26.

41. Rodrigo-Comino, J. Five decades of soil erosion research in "terroir". The State-of-the-Art. Earth-Sci. Rev. 2018, 179, 436-447. [CrossRef] 
42. Rodrigo-Comino, J.; Keesstra, S.; Cerdà, A. Soil Erosion as an Environmental Concern in Vineyards: The Case Study of Celler del Roure, Eastern Spain, by Means of Rainfall Simulation Experiments. Beverages 2018, 4, 31. [CrossRef]

43. Rodrigo-Comino, J.; Novara, A.; Gyasi-Agyei, Y.; Terol, E.; Cerdà, A. Effects of parent material on soil erosion within Mediterranean new vineyard plantations. Eng. Geol. 2018, 246, 255-261. [CrossRef]

44. IUSS Working Group WRB World Reference Base for Soil Resources 2014; World Soil Resources Report; FAO: Rome, Italy, 2014.

45. Rodrigo-Comino, J.; García-Díaz, A.; Brevik, E.C.; Keestra, S.D.; Pereira, P.; Novara, A.; Jordán, A.; Cerdà, A. Role of rock fragment cover on runoff generation and sediment yield in tilled vineyards. Eur. J. Soil Sci. 2017, 68, 864-872. [CrossRef]

46. Rodrigo-Comino, J.; Keesstra, S.D.; Cerdà, A. Connectivity assessment in Mediterranean vineyards using improved stock unearthing method, LiDAR and soil erosion field surveys. Earth Surf. Process. Landf. 2018, 43, 2193-2206. [CrossRef]

47. Pita, M.F.; Cuadrat, J.M. Climatología; Ediciones Cátedra: Madrid, Spain, 2006.

48. Gil Olcina, A.; Olcina Cantos, J. Tratado de Climatología; Universidad de Alicante: Alicante, Spain, 2017.

49. Haurwitz, B. Insolation in relation to cloudiness and cloud density. J. Meteor. 1945, 2, 154-166. [CrossRef]

50. Haurwitz, B. Insolation in relation to cloud type. J. Meteor. 1946, 3, 123-124. [CrossRef]

51. Haurwitz, B. Collaborators Advection of air and the forecasting of pressure changes. J. Meteor. 1945, 2, 83-93. [CrossRef]

52. Giambelluca, T.W.; Nullet, D. Influence of the trade-wind inversion on the climate of a leeward mountain slope in Hawaii. Clim. Res. 1991, 1, 207-216. [CrossRef]

53. Harrison, M.S.J. Elevated Inversions over Southern Africa: Climatological Properties and Relationships with Rainfall. S. Afr. Geogr. J. 1993, 75, 1-8. [CrossRef]

54. Li, Z.; Zuidema, P.; Zhu, P. Simulated Convective Invigoration Processes at Trade Wind Cumulus Cold Pool Boundaries. J. Atmos. Sci. 2014, 71, 2823-2841. [CrossRef]

55. Tompkins, A.M. Organization of Tropical Convection in Low Vertical Wind Shears: The Role of Cold Pools. J. Atmos. Sci. 2001, 58, 1650-1672. [CrossRef]

56. Xoplaki, E.; González-Rouco, J.F.; Luterbacher, J.; Wanner, H. Wet season Mediterranean precipitation variability: Influence of large-scale dynamics and trends. Clim. Dyn. 2004, 23, 63-78. [CrossRef]

57. Engelbrecht, F.A.; McGregor, J.L.; Engelbrecht, C.J. Dynamics of the Conformal-Cubic Atmospheric Model projected climate-change signal over southern Africa. Int. J. Climatol. 2009, 29, 1013-1033. [CrossRef]

58. Barros, A.P.; Lettenmaier, D.P. Dynamic modeling of orographically induced precipitation. Rev. Geophys. 1994, 32, 265-284. [CrossRef]

59. McCabe, G.J., Jr.; Muller, R.A. Synoptic Weather Types: An Index of Evaporation in Southern Louisiana. Phys. Geogr. 1987, 8, 99-112. [CrossRef]

60. Chu, P.-S.; Chen, H. Interannual and Interdecadal Rainfall Variations in the Hawaiian Islands. J. Clim. 2005, 18, 4796-4813. [CrossRef]

61. Yeh, H.-C.; Chen, Y.-L. Characteristics of Rainfall Distributions over Taiwan during the Taiwan Area Mesoscale Experiment (TAMEX). J. Appl. Meteor. 1998, 37, 1457-1469. [CrossRef]

62. Gaál, N.; Ihász, I. Evaluation of the cold drops based on ERA-Interim reanalysis and ECMWF ensemble model forecasts over Europe. Idojaras (Budapest 1905) 2015, 119, 111-126.

63. Romero, R.; Sumner, G.; Ramis, C.; Genovés, A. A classification of the atmospheric circulation patterns producing significant daily rainfall in the Spanish Mediterranean area. Int. J. Climatol. 1999, 19, 765-785. [CrossRef]

64. Wallis, T.W.R.; Griffiths, J.F. An assessment of the weather generator (WXGEN) used in the erosion/productivity impact calculator (EPIC). Agric. For. Meteorol. 1995, 73, 115-133. [CrossRef]

65. Fernández-Raga, M.; Fraile, R.; Keizer, J.J.; Varela Teijeiro, M.E.; Castro, A.; Palencia, C.; Calvo, A.I.; Koenders, J.; Da Costa Marques, R.L. The kinetic energy of rain measured with an optical disdrometer: An application to splash erosion. Atmos. Res. 2010, 96, 225-240. [CrossRef]

66. Sadeghi, S.H.; Nouri, H.; Faramarzi, M. Assessing the Spatial Distribution of Rainfall and the Effect of Altitude in Iran (Hamadan Province). Air Soil Water Res. 2017, 10, 1178622116686066. [CrossRef]

67. Wilby, R.L.; Dalgleish, H.Y.; Foster, I.D.L. The impact of weather patterns on historic and contemporary catchment sediment yields. Earth Surf. Process. Landf. 1997, 22, 353-363. [CrossRef] 
68. Pattison, I.; Lane, S.N. The relationship between Lamb weather types and long-term changes in flood frequency, River Eden, UK. Int. J. Climatol. 2012, 32, 1971-1989. [CrossRef]

69. Jones, P.G.; Thornton, P.K. Generating downscaled weather data from a suite of climate models for agricultural modelling applications. Agric. Syst. 2013, 114, 1-5. [CrossRef]

70. McNew, K.P.; Mapp, H.P.; Duchon, C.E.; Merritt, E.S. Sources and Uses of Weather Information for Agricultural Decision Makers. Bull. Amer. Meteor. Soc. 1991, 72, 491-498. [CrossRef]

71. Ramos, A.M.; Barriopedro, D.; Dutra, E. Circulation weather types as a tool in atmospheric, climate, and environmental research. Front. Environ. Sci. 2015, 3. [CrossRef]

72. Philipp, A.; Bartholy, J.; Beck, C.; Erpicum, M.; Esteban, P.; Fettweis, X.; Huth, R.; James, P.; Jourdain, S.; Kreienkamp, F.; et al. Cost733cat-A database of weather and circulation type classifications. Phys. Chem. Earth Parts A/B/C 2010, 35, 360-373. [CrossRef]

73. Fleig, A.K.; Tallaksen, L.M.; Hisdal, H.; Stahl, K.; Hannah, D.M. Inter-comparison of weather and circulation type classifications for hydrological drought development. Phys. Chem. Earth Parts A/B/C 2010, 35, 507-515. [CrossRef]

74. Gu, C.; Mu, X.; Gao, P.; Zhao, G.; Sun, W.; Tan, X. Distinguishing the effects of vegetation restoration on runoff and sediment generation on simulated rainfall on the hillslopes of the loess plateau of China. Plant Soil 2020, 447, 393-412. [CrossRef]

75. Zhang, X.; Wu, K.; Fullen, M.A.; Wu, B. Synergistic effects of vegetation layers of maize and potato intercropping on soil erosion on sloping land in Yunnan Province, China. J. Mt. Sci. 2020, 17, 423-434. [CrossRef]

76. Luo, J.; Zhou, X.; Rubinato, M.; Li, G.; Tian, Y.; Zhou, J. Impact of Multiple Vegetation Covers on Surface Runoff and Sediment Yield in the Small Basin of Nverzhai, Hunan Province, China. Forests 2020, 11, 329. [CrossRef]

77. Amare, T.; Zegeye, A.D.; Yitaferu, B.; Steenhuis, T.S.; Hurni, H.; Zeleke, G. Combined effect of soil bund with biological soil and water conservation measures in the northwestern Ethiopian highlands. Ecohydrol. Hydrobiol. 2014, 14, 192-199. [CrossRef]

(C) 2020 by the authors. Licensee MDPI, Basel, Switzerland. This article is an open access article distributed under the terms and conditions of the Creative Commons Attribution (CC BY) license (http://creativecommons.org/licenses/by/4.0/). 